\title{
Dietary Sulfur and Phosphorus Supplementation on Kacang Goats Fed Diet Containing Fermented Oil Palm Fronds
}

\section{T. Astuti ${ }^{1 *}$, A. Jayanegara ${ }^{2}$, U. Santoso ${ }^{3}$, Syahro A. Akbar $^{1}$}

${ }^{1}$ Department of Animal Science, Faculty of Agriculture Mahaputra Muhammad Yamin University, Jl. Jend. Sudirman No. 6 Solok City, West Sumatera Indonesia; ${ }^{2}$ Department of Nutrition and Feed Technology, Faculty of Animal Science, IPB University, Jl. Agatis Kampus IPB Dramaga Bogor 16680, Indonesia; ${ }^{3}$ Department of Animal Science, Faculty of Agriculture, IPB University, Jalan Raya W.R. Supratman, Kandang Limun, 38371A, Bengkulu, Indonesia.

\begin{abstract}
The research purpose to evaluate the effect of sulfur and phosphorus supplementation in the complete feed-based fermented oil palm fronds (OPF) on the nutrient digestibility, consumption of feed, average daily gain, and feed efficiency of Kacang goats. Using the completely randomized design by 4 treatments with 4 replicates for the analysis in vitro method of diet and a block randomized design for the performance of goats in this research. The diet treatment consisted of $40 \%$ fermented $\mathrm{OPF}+60 \%$ concentrates. The dietary treatments consisted of $\mathrm{R} 1=$ control ration ( $40 \%$ fermented $\mathrm{OPF}+60 \%$ concentrate) without sulfur and phosphorus supplementation. $\mathrm{R} 2=\mathrm{R} 1+0.4 \%$ sulfur, $\mathrm{R} 3=\mathrm{R} 1+0.27 \%$ phosphorus, and $\mathrm{R} 4=\mathrm{R} 1+0.4 \%$ sulfur $+0.27 \%$ phosphorus. The results of this experiment showed the significant effect of the sulfur and phosphorus supplementation in the complete feed on dry matter and organic matter digestibility $(p<0.05)$, but no effect on; crude; protein, fiber, and the performance of goats. It could be concluded that the sulfure and phosphorus supplementation had no effects on feed intake, daily gain, and feed efficiency of Kacang goats.
\end{abstract}

Keywords | Sulfur, Phosphorus, Complete feed, Oil palm frond, Fermented

Received | April 28, 2021; Accepted | September 17, 2021; Published | November 15, 2021

*Correspondence | T. Astuti, Department of Animal Science, Faculty of Agriculture Mahaputra Muhammad Yamin University, J1. Jend. Sudirman No. 6 Solok City, West Sumatera Indonesia; Email: adektuti@gmail.com

Citation Astuti T, Jayanegara A, Santoso U, Akbar SA (2021). Dietary sulfur and phosphorus supplementation on kacang goats fed diet containing fermented oil palm fronds. Adv. Anim. Vet. Sci. 9(12): 2221-2224.

DOI | http://dx.doi.org/10.17582/journal.aavs/2021/9.12.2221.2224

ISSN (Online) | 2307-8316; ISSN (Print) | 2309-3331

Copyright (C) 2021 Astuti et al. This is an open access article distributed under the Creative Commons Attribution License, which permits unrestricted use, distribution, and reproduction in any medium, provided the original work is properly cited.

\section{INTRODUCTION}

I ndonesia is one; of the largest producer plantation of palm oil in the world's with a total area of approximately 11,300,400 ha (Statistic Indonesia, 2019). Plantation technology has reached to zero waste. Almost every part of the tree has been studied for its application in various fields including energy, food, materials, manufacturing and so forth. In the field of veterinary, the oil palm leaves or pruned oil palm fronds (OPF) have been found suitable for feeding the goats. The availability of OPF has the potential to be used as ruminant feed as a substitute for forage. Warly et al. (2017). The dry matter and crude protein digestibility of 60\% OPF in Simmental cattle were 59.40\% and $59.40 \%$. Unfortunately, the disadvantage of OPF have their high lignin content and the low of digestibility nutrients. Astuti's Researched (2017) the lignin content of OPF mixed with concentrate was $11.64 \%$. The dry matter and organic matter digestibility of OPF was $35,47 \%$ and 53, 68\% (Tahsin et al., 2018).

The technology of fermentation could improve the nutritional contents of feeds, and increase their biological values when being utilized by animals (Steinkraus, 2002). Some fermentation studies of animal feeds used commercial microorganisms of fungi, bacteria, and others, but in this research, the OPF were fermented by the source of the local microorganism of the rumen liquor. Astuti et al. (2016) use of local waste as a source of microorganisms was very profitable because of the cheaper cost and the process 
was easier. Furthermore, Astuti et al. (2019) reported that fermentation process OPF by local microorganisms of the rumen liquor, and Lactobacillus sp. with the addition of water-soluble carbohydrates could decrease the content of ADF, NDF, cellulose, and lignin of OPF. Akin et al. (1983) described that the microbes could be stimulated by adding sulfur, and improved animal weight gain. Rumen microbes could use sulfur to synthesize sulfur-containing amino acids (Karto, 1999). Sulfur (S) is part of cysteine and methionine (Richter, 2011) and a precursor for the other S-containing amino acid (NRC, 2000). Sulfur deficiency decreased the growth of rumen microbes and reduced their contribution to forage digestion (Bal and Ozturk, 2006). A lower phosphorus content in the rumen causes reduce rumen microbial growth and thereby reduces cellulose degradation (Witt and Owens, 1981). This researc purpose to analyze the effect of sulfur and phosphorus supplementation in complete feed-based fermented OPF on the production performance and nutrient digestibility of Kacang goats. The supplementation of sulfur and phosphorus in the diet treatment be thought to affect the digestibility of nutrients and the production performance of goats.

\section{MATERIALS AND METHODS}

\section{FEED PREPARATION}

The rumen liquors were taken from the abattoir and put into a tube, added with sugar and coconut water to feed microorganisms, then incubated for 10 days with anaerobic (Astuti et al., 2016). This mixture was called local microorganisms. Crushed OPF was mixed with these local microorganisms and then incubated for 7 days to generate the fermented OPF.

The complete feed was composed of fermented OPF (as a forage) and concentrate mixture. The ration formulation consisting of forage and concentrates base on the nutritional requirements of Kacang goats. The mixture or complete feed was made into biscuit by pressing and drying procedures, and each biscuit had a dimension of $5 \times 7 \times 2$ $\mathrm{cm}^{3}$. The complete feed biscuits were light brown in color cause of a non-enzymatic browning reaction. The purpose of making biscuits is to reduce dust, increase palatability, reduce feed residue, reduce feed volume, and facilitate handling, storage, and transportation (Saenab et al., 2010).

\section{EXPERIMENTAL ANIMALS}

A total of 16 Kacang goats (body weight ranged from 9.5 to $24.7 \mathrm{~kg}$ ) were employed in the present experiment. Guideline for ethics study of experimental animals based on the law of the Republic of Indonesia number 18 of 2009 about Animal livestock and animal husbandry. All the goats were placed in individual cages and received experimental diets at a level start of $3 \%$ body weight on a dry matter basis. Kearl (1982) stated that the nutrient requirement of goat (BW10-20 kg, ADG $75 \mathrm{~g}$ ) is about $3.1-3.5 \%$ of body weight). The goats were obtained from the farmers who have kept the previous extensification. Thus, it need the preliminary and introduction fase before starting experiment.

\section{EXPERIMENTAL DESIGN AND DATA ANALYSIS}

The research design has done using a completely randomized with four treatments and four replicates. The dietary; treatments consisted of $\mathrm{R} 1=$ control ration (40\% fermented OPF $+60 \%$ concentrate) without sulfur and phosphorus supplementation. R2 $=\mathrm{R} 1+0.4 \%$ sulfur, $\mathrm{R} 3=\mathrm{R} 1+0.27 \%$ phosphorus, and $\mathrm{R} 4=\mathrm{R} 1+0.4 \%$ sulfur + $0.27 \%$ phosphorus. A block randomized design was used to evaluates the performances of goats. The formulation; of ration treatment were presented in Table 1.

Table 1: Formulation of complete feed based on fermented oil palm fronds.

$\begin{array}{lllll}\text { Feedstuffs (\%) } & \text { R1 } & \text { R2 } & \text { R3 } & \text { R4 } \\ \text { Fermented oil palm fronds } & 40 & 40 & 40 & 40 \\ \text { Rice bran } & 13 & 13 & 13 & 13 \\ \text { Cassava flour } & 13 & 13 & 13 & 13 \\ \text { Palm sugar } & 8 & 8 & 8 & 8 \\ \text { Tofu waste } & 8 & 8 & 8 & 8 \\ \text { Anchovy head flour } & 17 & 17 & 17 & 17 \\ \text { Mineral } & 1 & 1 & 1 & 1 \\ \text { Total } & 100 & 100 & 100 & 100 \\ \text { Sulfur } & 0 & 0.4 & 0 & 0.4 \\ \text { Phosphorus } & 0 & 0 & 0.27 & 0.27\end{array}$

The observed variables in the present study were nutrient digestibility such as dry matter (DM), organic matter $(\mathrm{OM})$, crude protein $(\mathrm{CP})$ and crude fiber $(\mathrm{CF})$ digestibilities. The performances of goats such as feed intake, daily gain, feed efficiency wee also measured. Moisture, CP, CF, and ash were analyzed using the AOAC method (AOAC, 2011), while the nutrient digestibility was measured using an in vitro rumen fermentation technique (Tilley and Terry, 1963).

The analysis of variance used to analyze all data and continued using Duncan's multiple range tests when a certain variable showed significance at $\mathrm{P}<0.05$.

\section{RESULTS AND DISCUSSION}

\section{NutRIENT DigESTIBILITY}

The nutrient digestiblity of the experimental diets is presented in Table 2. The experimental results showed 
that dry matter and organic matter digestibilities were significantly affected $(\mathrm{P}<0.05)$, whereas crude fibre and crude protein digestibilities did not signficantly affected $(\mathrm{P}>0.05)$. It was showed that $\mathrm{R} 1$ had;more lower DM digestibility than $\mathrm{R} 2$.

Table 2: Dry matter, organic matter, crude fiber and crude protein digestibilities of the experimental diets.

\begin{tabular}{llllll} 
Variables (\%) & \multicolumn{5}{c}{ Dietary treatments } \\
& R1 & R2 & R3 & R4 & SE \\
Dry matter & $72.7^{\mathrm{b}}$ & $84.9^{\mathrm{a}}$ & $78.5^{\mathrm{a}}$ & $76.7^{\mathrm{a}}$ & 0.54 \\
\hline Organic matter & $69.3^{\mathrm{b}}$ & $82.8^{\mathrm{a}}$ & $75.7^{\mathrm{a}}$ & $73.8^{\mathrm{ab}}$ & 0.62 \\
Crude fibre & 52.5 & 45.2 & 48.5 & 42.8 & 0.54 \\
Crude protein & 66.7 & 61.5 & 52.4 & 52.1 & 1.18
\end{tabular}

Note: Different superscripts within the same row are statistically different at $\mathrm{P}<0.05$. R1= control ration $(40 \%$ fermented OPF $+60 \%$ concentrate), without sulfur and phosphorus supplementation, $\mathrm{R} 2=\mathrm{R} 1+0.4 \%$ sulfur, $\mathrm{R} 3=\mathrm{R} 1+0.27 \%$ phosphorus, and R4= R1 + 0.4\% sulfur $+0.27 \%$ phosphorus, R3 and R4 (P>0.05). R2 had also lower OM digestiblity than R2 and $\mathrm{R} 3$ but relatively similar to $\mathrm{R} 4$.

\section{Performance of KaCANG gOATS}

Table 3 shows the effect of experimental diets on feed intake, feed efficiency, and daily gain;of Kacang goats. Experimental results shows that feed intake, feed efficiency and daily gain were not siginficantly affected by the treatments $(\mathrm{P}>0.05)$.

Table 3: Effects of experimental diets on feed intake, daily gain and feed efficiency of Kacang goats.

\begin{tabular}{llllll} 
Variables & \multicolumn{5}{c}{ Dietary treatments } \\
& R1 & R2 & R3 & R4 & SE \\
Feed intake (g/d) & 480 & 470 & 462 & 467 & 1.69 \\
Daily gain (g/d) & 52.2 & 16.6 & 30.2 & 27.3 & 2.14 \\
Feed efficiency (\%) & 11.0 & 3.52 & 6.55 & 5.85 & 0.45 \\
Note: R1= control & ration & $(40 \%$ & fermented & OPF & $+60 \%$ \\
concentrate), without sulfur and phosphorus supplementation, \\
R2= R1 + 0.4\% sulfur, R3= R1 + 0.27\% phosphorus, and R4= R1 \\
+ 0.4\% sulfur + 0.27\% phosphorus.
\end{tabular}

\section{NUTRIENT DIGESTIBILITY}

It is quite interesting that the $0.4 \%$ sulfur in the feed formulation (R2) had higher the digestibility of both dry matter and organic matter as compared with the phosphorus (R3) and the sulfur-phosphorus mixture (R4). The supplementation of sulfur and phosphorus to the complete feed based on OPF may be unable to optimize the functioning of rumen microbes to produce the fiber and protein digestive enzymes. Tahsin et al. (2018) reported that the digestibility of DM and OM of fermented OPF were 58.56 and $73.88 \%$, respectively.
The sulfur supplementation failed to improve the crude protein and crude fiber digestiblilities. It is possible that the dose of sulfur was unadequate to upgrade the functioning of rumen microbes. This result was different from Zain et al. (2010) who reported that sulfur supplementation to the rice straw ammoniation could improve the $\mathrm{DM}, \mathrm{OM}, \mathrm{CP}$, and $\mathrm{CF}$ digestibilities.

\section{Performance of Kacang goats}

The supplementation of sulfur and phosphor to the complete feed based on fermented OPF did not affect the palatability resulting in similar feed intake. The feed intaked on this research about $462-480 \mathrm{gram} / \mathrm{head} /$ day. The result of this research was similar to the research of Nurhaita et al. (2014) who declare that the average of feed intake ranged from $307.25 \%-375.79 \% \mathrm{~g} / \mathrm{head} /$ day. The feed inatke result of this research was lower than Musnandar et al. (2011) who reported that the average of feed intake was $895.87 \mathrm{~g} /$ day.

The goats weight daily gain, feed intake and feed efficiency were not affected by sulfur and phosphor supplementation. The daily gain of goats research about 16.6-52.2 gram/day, and the highest on R1 treatment (control ration without supplementation $\mathrm{S}$ and $\mathrm{P}$ ). This was because the Kacang goats have typically small size of weight and the low of daily gain (Setiadi, 2003), and suspect doses of suplementation $\mathrm{S}$ and $\mathrm{P}$ not affect the activity rumen microbe of goats in this research.

The result of this researched was similar with the Saragih Research (2014) that used OPF silage as feeding of kacang goats, and getting about $9.14-50.57 \mathrm{gram} / \mathrm{head} /$ day daily gain.

\section{CONCLUSIONS AND RECOMMENDATIONS}

Supplementation of sulfur and/or phosphorus improved DM and OM digestibility but had no effects on CP and $\mathrm{CF}$ digestibility. The supplementation had no effects on feed intake, daily gain and feed efficiency of Kacang goats.

\section{ACKNOWLEDGMENTS}

Thank you so much to the Directorate Research and Community Service, the Indonesian Ministry of Education and Culture has funded this research

\section{NOVELTY STATEMENT}

This Formulation of complete feed based on fermented oil palm fronds only used in this research. 


\section{AUTHOR'S CONTRIBUTION}

All authors contributed in this research, statistical analysis, of the results, and approved the final manuscript.

CONFLICT OF INTEREST

The authors have declared no conflict of interest.

\section{REFERENCES}

-Akin DE, Gordon GL, Hogan JP (1983). Rumen bacterial and fungal degradation of Digitaria pentzii grown with or without sulfur. Appl. Environ. Microbiol., 46(3): 738-748. https://doi.org/10.1128/aem.46.3.738-748.1983

-AOAC (2011). Official methods of analysis of the Association of Official Analytical Chemists International. In Recovery studies, $17^{\text {th }}$ edn. Byrd Richmond, VA.

-Astuti T, Amir Y, Santoso U, Irdawati (2016). Nutritional improvement of palm oil fronds for ruminant feedstuffs using a local biotechnological approach. 15(27): 450-454. https://doi.org/10.3923/pjn.2016.450.454

-Astuti T, Santoso U, Amir Y (2017). Nutritional value of fermented palm oil fronds as a basis for complete feed for ruminants. Pak. J. Nutr., 16(2): 96-100. https://doi. org/10.3923/pjn.2017.96.100

-Astuti T, Rofiq MN, Santoso NU (2019). Analysis of fibre fraction of palm oil frond fermented with different microbes and soluble carbohydrates addition as ruminant feeding. IOP Conf. Ser. Earth Environ. Sci., 347: 012059. https:// doi.org/10.1088/1755-1315/347/1/012059

-Bal MA, Ozturk D (2006). Effect of sulfur containing supplements on ruminal fermentation and microbial protein synthesis. Res. J. Anim. Vet. Sci., 1: 33-36.

-Kearl LC (1982). Nutrient Requirements of Ruminants in Developing Countries. Logan. Utah: Utah Syate University.

- Musnandar E, Hamidah A, Muthalib RA (2011). The effect of fermented oil palm fronds in diet on body weight gain and meat quality of goat. J. Indonesian Trop. Anim. Agric., 36(2): 120-125. https://doi.org/10.14710/jitaa.36.2.120-125

- NRC (2000). Nutrient requirements of beef cattle. $7^{\text {th }}$ Rev. Edn., National Academic Press, Washington, DC., USA, pp. 242.

-Nurhaita, Ruswendi R, Wismalinda, Robiyanto (2014). Utilization of palm oil frond as forage source in cattle ration. J. Pastura, 4(1): 38-41. https://doi.org/10.12720/ joaat.1.1.10-13

- Karto AA (1999). Peran dan kebutuhan sulfur pada ternak ruminansia. Wartazoa, 8(2): 38-44.

- Richter EL (2011). The effect of dietary sulfur on performance, mineral status, rumen hydrogen sulfide, and rumen microbial populations in yearling beef steers. Thesis. Iowa State University.

-Saenab A, Laconi EB, Retnani Y, Mas'ud MS (2010). Quality evaluation of shrimp by product complete ration pellets. J. Ilmu Ternak dan Vet., 15: 31-39.

-Saragih H (2014). Penggunaan limbah perkebunan untuk pengembangan ternak kambing. Wahana Inovasi, 3(1): 157162.

-Setiadi B (2003). Alternatif konsep pembibitan dan Pengembangan Usaha Ternak Kambing. Makalah Sarasehan "Potensi Ternak Kambing dan Propek Agribisnis Peternakan”, 9 September 2003 di Bengkulu

- Statistic Indonesia (2019). https://www.bps.go.id/

- Steel R, Torrei J, Dickey D (1997). Principles and procedures of statistics a biometrical approach. Biomet. Approach.

-Steinkraus KH (2002). Fermentations in world food processing. Comp. Rev. Food Sci. Food Saf., https://doi. org/10.1111/j.1541-4337.2002.tb00004.x

-Tahsin M, Khairani Y, Hanafi ND, Yunilas (2018). In vitro digestibility of oil palm frond treated by local microorganism (MOL). IOP Conf. Ser. Earth Environ. Sci., 122: 012134. https://doi.org/10.1088/1755-1315/122/1/012134

-Tilley JMA, Terry RA (1963). A two-stage technique for the in vitro digestion of forage crops. Grass Forage Science. https://doi.org/10.1111/j.1365-2494.1963.tb00335.x

-Warly L, Suyitman, Evitayani, Fariani A (2017). Nutrient digestibility and apparent bioavailability of minerals in beef cattle fed with different levels of concentrate and oil-palm fronds. Pak. J. Nutr., 16(3): 131-135. https://doi. org/10.3923/pjn.2017.131.135

-Witt KE, Owens FN (1981). Ruminal availability of phosphorus and its effect on digestion. Anim. Sci. Res. Rep., pp. 151-157. http://beefextension.com/research_reports/ research_56_94/rr81/rr81_44.pdf.

-Zain M, Jamarun N, Nurhaita (2010). Effect of sulfur supplementation on in vitro fermentability and degradability of ammoniated rice straw. Pak. J. Nutr., 9(5): 413-415. https://doi.org/10.3923/pjn.2010.413.415 